\title{
Lubomír Kopeček: Fenomén Václav Klaus. Politická biografie
}

\author{
Brno: Barrister\&Principal 2012, 315 s., ISBN 978-80-87474-75-4
}

\section{Ladislav Cabada $^{1}$}

Lubomír Kopeček je odborné i širší veřejnosti zabývající se středoevropskou politikou a soudobou historií dobře znám jako plodný autor monografií i dalších vědeckých publikací. Vedle badatelských prací oprených o výrazný teoretický a metodologický aparát nabízí v posledním období tento autor širšímu okruhu potenciálních čtenářů rovněž populárněji zaměřené práce. Z nich jako dosud nejvýraznější musíme zmínit knihu Éra nevinnosti. Česká politika 1989-1997 (2010), ve které Kopeček přesvědčivě ukázal schopnost citlivě najít rovnováhu mezi využitím odborných př́stupů k analýze a požadavkem „čtivosti“, jenž se logicky váže k spíše popularizační literatuře. Již před třemi lety přitom Kopeček ukázal, že je schopen velmi citlivého a důvěryhodného př́stupu k politické matérii i při změně základní, „metateoretické“ pozice od nestranného badatele kvýrazně normativněji ukotvené pozici pozorovatele, analytika a hodnotitele. I když se autor v úvodu recenzované práce deklarativně přihlašuje $\mathrm{k}$ vybraným aspektům svého světonázoru či ideově-politického zaměření, rozhodně nelze potvrdit jeho obavu, že by mohl či měl být označován jako „nekritický Klausovec“. Jeho analýza bezpochyby je normativně podbarvená, nicméně současně velmi věcná, odmítající černo-bílé vidění věcí, reflektující slabé i silné stránky povahy a konání jak Václava Klause, tak i jeho spolu- či protihráčů na české a evropské politické scéně.

Kopeček byl a je v př́ipadě předkládané politické biografie v obtížnější situaci, než tomu bylo u jeho práce $z$ roku 2010. Zatímco v knize Éra nevinnosti se analyticky zaměřil na fakticky ukončenou periodu „zlatých let“ české polistopadové politiky, jeho nová populární monografie obsáhla ve vazbě na klíčového aktéra většiny polistopadových politických dějů více než dvě dekády. $\mathrm{Na}$ jedné straně se $\mathrm{v}$ delším období dají nejen $\mathrm{v}$ př́padě hlavního hrdiny lépe rozlišit dlouhodobějši trendy, či naopak zvraty, lze nabídnut bohatši škálu výher a proher, dílčích úspěchů a neúspěchů. Na druhou stranu nutně musí autor zvolit selektivnější př́stup, nap̌r. ve vazbě na dle jeho soudu nejvýraznější názorové postoje (či přemety) prezentované osoby, resp. nejviditelnější vrcholy životní „sinusoidy“ V tomto ohledu má žánn politického životopisu samozřejmě relativně jasná pravidla, včetně hledání náznaků „politické profilace“ v období předpolitickém apod. Svou knihu Kopeček navíc spojil s ukončením výrazné periody v životě jejího hlavního aktéra, tedy doběhnutím druhého Klausova pětiletého prezidentského mandátu, nicméně $\mathrm{i}$ autor sám $\mathrm{v}$ textu opakovaně naznačuje, že tento okamžik nelze ztotožnit s koncem Klausova politického angažmá; což se ostatně záhy po Klausově odchodu z „Hradu“ potvrdilo. Jedná se tedy o „prozatímní“ biografii, u níž se dá předpokládat pozdější doplnění či alespoň poměrně rozsáhlá revize. Tato skutečnost však nic nemění na tom, že Kopečkova kniha je zralým, analyticky hodnotným a čtivým textem.

\footnotetext{
${ }^{1}$ Katedra politologie a humanitních studií, Metropolitní univerzita Praha. Dubečská 900/10, 11031 Praha 10 Strašnice e-mail: cabada@mup.cz
} 
Vlastní struktura sleduje časovou linku, když po stručném Prologu reflektujícím důležité mezníky Klausova života následuje autorův pokus o sondu do Klausova způsobu uvažování. Zde vidím jako velmi podstatné zejména zamyšlení nad „středostavovským“ rodinným zázemím, které Klause silně formovalo (jeho citlivý vztah k matce tvořil v polistopadových letech zajímavý kontrast se začasté „necitlivým“ zpo̊sobem, jakým Klaus peskoval své politické soupeře a dokonce i souputníky; a zlidšt’oval jej) a také poukaz na „protestantskou etiku“ založenou na pracovitosti a soutěživosti. Za širší rozvedení by nicméně stála autorem pouze naznačená tendence Václava Klause preferovat cíl před způsobem, jakým jej bylo dosaženo. Kopeček na str. 18 na základě Klausova postoje k „Maradonově Boží ruce“ vyvozuje, že ocenil hráčovu snahu udělat pro vítězství vše. Takové hodnocení je jistě možné, nicméně určitě by bylo zajímavé dát ho do širších souvislostí jak s českou „národní povahou“ (Klaus určitě není obdivovatelem Haškova „Švejka“, ale uvažuje vlastně podobně jako tento literární hrdina, který v diskusi nad rozstř́leným sanitním vlakem konstatuje, že zásah to byl dobrý a on se pak každý rád omluví, že trefil zakázaný cíl), resp. s v českém (post)komunistickém diskursu tolikrát reflektovaný výrok, že „účel světí prostředky“.

Vlastní biografii následně Kopeček rozděluje do devíti kapitol, které v časové linii od Listopadu 1989 do roku 2012 sledují Klausovo počínání na české a evropské politické scéně v širším kontextu hledání stabilních či proměnlivých kontur Klausova politického uvažování. Názvy jednotlivých kapitol (např. „Tatičcek ochranitel", Proti v̌rem či Politický alarmista) vtipně vystihují klíčovou determinantu analyzované periody. Kopeček zde naznačuje důležitý potenciál pro popularizační práci, tj. schopnost čtenáře oslovit, zaujmout; staví se tak navíc do zajímavé (o)pozice vůči zkoumanému subjektu, protože právě Klaus vnesl na českou politickou scénu velmi důležitou schopnost vnutit do politického a veřejného diskursu vlastní pojmosloví včetně novotvarů (např̀. opoziční smlouva, toleranční patent či dnes již zlidovělá „nevýhra“).

K prvnímu politickému vrcholu se podle Kopečka Klaus propracoval již během necelého prvního roku po Listopadu 1989. Za tento vrchol autor dle mého soudu zcela správně považuje Klausův podíl na „rozdělení OF, vytvoření ODS a nastartování klasické politické soutěže“ (str. 41). Naopak jako historicky nepřesnou vidí personifikaci ekonomické transformace včetně její vlajkové lodi - kupónové privatizace - právě s Klausem. Analýza širších kontur tohoto procesu včetně proměny některých Klausových postojů dobře ukazují tápání nejen tohoto politika, ale všech hlavních architektů „velké transformace“ v periodě budování „kapitalismu s lidskou tváříc (připomeňme kousavou Rupnikovu poznámku o tom, že míra transformace v podání ODS by byla v západní Evropě chápána jako sociálně-demokratická, a nikoli liberálně-konzervativnî). Kopeček jako největší chybu vlád vedených Klausem detekuje odkládání privatizace bank (str. 69), které z těchto (polo)státních molochů činilo hlavní aktéry toho, co Lubomír Mlčoch označuje jako private recombined ownership, tedy paskvil, kdy hlavním zdrojem kapitalizace celého privatizačního procesu se stávají banky kryté státním rozpočtem. Byla to tedy Klausova „česká cesta“, nicméně generující zásadní problémy spojené s držením pasiv v rámci státních bank. Když předběhneme, právě tápání v pozici předsedy vlády (zejména po roce 1996) vidí Kopeček jako jeden ze tří největších Klausových politických přehmatů (str. 278). 
Plně s Kopečkem souhlasím i u dalšího analyzovaného tématu, a to vztahu V. Klause k (anti)komunismu a dekomunizační agendě - ODS pod Klausovým vedením zásadně přispěla $\mathrm{k}$ přijetí poměrně striktního lustračního zákona (ponechme stranou, jak byl a je v praxi naplňován), na druhé straně Klaus dokázal poměrně citlivě a pragmaticky brzdit radikální antikomunismus, který coby hlavní téma (mnohdy dokonce ve spojení s teorií spiknutí poukazující na údajnou dohodu mezi novou politickou elitou a předlistopadovými aktéry) užívaly Klub angažovaných nestraníků či Demokratická unie. Plně akceptuji i reflexi Klausova negativního postoje k otázce restitucí; na druhé straně by možná právě u tohoto tématu bylo možné uvažovat o exkurzu diskutujícím možnosti a limity „konzervatismu“ v postkomunistickém prostoru obecněji a nivelizované české společnosti s negativním vztahem k „tradičním“ elitám konkrétně.

Jako druhou výraznou chybu (autor dokonce hovoří o „největší chybě kariéry“), které se Klaus dopustil, detekuje Kopeček lpění na tzv. opoziční smlouvě, již v roce 1998 uzavřely ČSSD a ODS. Tolerance vzniku menšinové vlády ČSSD ze strany ODS byla logickým řešením situace silné polarizace spektra relevantních politických stran; v tom se s autorem plně shoduji. Podobně podporuji i jeho názor, že prodlužování podpory slabé a personálně velmi problematické vládě Miloše Zemana i po roce 2000 - v situaci, kdy se pro média a voliče hlavní tváří ČSSD stal Vladimír Špidla - bylo velkou politickou chybou, za niž ODS v roce 2002 zaplatila další volební prohrou. Jak autor velmi explicitně konstatuje: „Klaus musel být slepý, jestliže ... distanc od opoziční smlouvy u nového lídra ČSSD neviděl““ (str. 132-133). Kopeček prritom velmi přesně vystihuje silnou personalizaci ODS s Klausem po odštěpení Unie svobody, resp. poté, co v roce 1998 do sněmovny vstoupil téměř kompletně personálně obměněný klub ODS, v němž se Klaus stal nezpochybnitelným králem a pro mnohé také guru. Právě absenci „korektivu“ vidí jako klíčovou determinantu volebního neúspěchu ODS v roce 2002.

Po volební prohře a tápání se Klaus rozhodnul opustit vedení ODS a zacílil směrem $\mathrm{k}$ chystané volbě nového prezidenta. Kopeček přesvědčivě ukazuje na pragmatismus Klause i ODS, kteři v tomto okamžiku začali hovořit o možnosti prímé volby prezidenta, jež by pro Klausovu aspiraci bezpochyby byla výhodnější. Rozklad ČSSD a současně velmi konciliantní Klausovo chování v rámci vlastní volby - opět Kopečkem citlivě a přesně reflektované: „Naježeného a arogantního politika vystřídal v rozhovorech ... usměvavý a konsensuálně vystupující člověk“ (str. 146) - nicméně vedly k překvapivému úspěchu i v rámci volby nepřímé, z níž se zrodil „tatíček ochranitel“, resp. konzervativně a národně orientovaný prezident, „romantický nacionalista“ Klaus. V rámci prvního mandátu si Kopeček všímá zejména utlumení mechanismu amnestií oproti Klausovu předchůdci (zde nicméně př́padné další vydání knihy nutně volá po revizi zejména v souvislosti s aktivitami sklonku Klausova druhého mandátu, tedy poměrně širokou amnestii), výrazné cestovní i publikační aktivity a rovněž ochlazování vztahů s ODS. Navzdory četným atakům nicméně vedení ODS na čele s Mirkem Topolánkem dokázalo Klause protlačit (velmi odpudivou, jak autor také reflektuje) parlamentní volbou do druhé mandátu.

V rámci druhého funkčního období se pak Klaus Kopečkovými slovy „odbrzdil“, resp. postavil „proti všem“. Jako velmi významné prezentuje autor Klausovo silné nasazení ve 
prospěch zachování české národní měny včetně personálních tahů v rámci České národní banky. $\mathrm{Na}$ odvrácené straně Klausových „bojư“ stojí jeho nepromyšlená podpora šéfovi sdružení D.O.S.T, L. Bátorovi, tedy figuře vysoce problematické co se týče politických postojů, názorů na hraně radikalismu či extremismu i angažmá v politických subjektech téhož charakteru.

V závěru své analýzy Kopeček ke Klausovým „velkým činům“ vedle přerodu OF v ODS a udržení české koruny přrřazuje ještě jednu zásluhu, a to podíl na klidném rozdělení Československa. Můžeme-li zejména vưči otázce potřeby bránit se vstupu do eurozóny vznést i řadu oponentních tvrzení, pak právě rozdělení Československa skutečně představuje vrchol Klausova politického působení, jenž z něj činí státníka. Byl to zřejmě - a poněkud paradoxně jeho pragmatický charakter (a Kopečkem opakovaně zmiňovaná nechut' k násilî), který jej vedl $\mathrm{k}$ řadě ústupků autoritativně vystupujícímu vedení HZDS na čele s Vladimírem Mečiarem. Dekonstrukce státu, který ztratil ideu, resp. za jehož ideu už se žádný významný proud či skupina nestavěly, byly velmi dobře zvládnutým krizově-manažerským aktem, za nějž Klaus patři do historických učebnic. Naopak řada dalších věcí dřive či později bude překryta či zapomenuta. I proto je nutné Kopečkovu politickou biografii velmi přivítat.

V úvodu recenze jsem naznačil, že autor je nutně selektivní. I s ohledem na možnost dopracování knihy $\mathrm{v}$ rámci dalšího vydání bych chtěl zmínit dva body, které považuji za velmi důležité. Prvním je Klausův vztah k médiím. Kopeček sice zejména v rámci diskuse o volební kampani ODS pro volby do Poslanecké sněmovny v roce 2002 naznačuje Klausovu chybu spojenou s jeho negativním postojem k médiím. Dle mého soudu by nicméně kniha zasluhovala obsáhlejší pasáž zabývající se Klausovou pozicí na/vǔči mediální scéně. Zejména mne v této souvislosti napadá jeho vstřícný postoj k soukromé televizi Nova (a vice versa), a to zejména po tzv. „narovnání“ v souvislosti s informacemi, jež tato stanice na přelomu let 1997/1998 šírila o údajné Klausově vile ve Švýcarsku. Podobně zajímavým tématem je Klausův vztah k bulvárním médiím, k nimž byl téměř podobně vstř̌́cný jako jeho velká fanynka Lucie Bílá. Druhý tématem, jež je v první fázi s médii svázáno, je Klausova vazba k Janě Bobošíkové. Tato politička prodělala od chvíle, kdy Klause adorovala v České televizi i jako moderátorka debat v TV Nova, poměrně zajímavou dráhu, která se četně prolínala i s Klausovou pozicí „proti všem“.

Mám-li v závěru recenze Kopečkovu knihu shrnout, pak je to inteligentní a poutavá odborně-populární analýza, která je jedním z těch textů, které mají potenciál zmenšovat př́kop mezi politologickou obcí a „zainteresovanou veřejností“. Přirozeně může být Kopečkovo dílo kritizováno jak z pozic politologických (jak jsem místy činil i já), tak i z pozic neodborných (jako stále přiliš odborné, užívající nadměrně odborné pojmy apod.). Konstatuji nicméně, že se jedná o knihu, která v sobě nese mnohé pozitivní znaky, jež si zpravidla spojujeme s tzv. anglosaskou populárně-politickou produkcí. S ohledem na postavu, která je v knize analyzována, přitom autor a vydavatel mohou - a měli by - uvažovat i o přenesení díla na mezinárodní rovinu. 